\section{Calcium Ions and the Permeability of Human Red Cells}

IT is well known that many tissues when placed in an electrolyte medium are profoundly affected by the presence or absence of calcium ions. This is also true of the red cells of the tortoise ${ }^{1}$, of the snapping turtle ${ }^{2}$ and probably of the red cells of certain fishes ${ }^{3-5}$, which in a calcium-free electrolyte medium become highly permeable to cations, and hence swell and rupture (hæmolysis). The red cells of the frog, chicken and of Mammalia, however, are little affected by suspension in calcium-free sodium chloride solution, exchange of cations with the external medium being very slow, and hæmolysis correspondingly delayed. Nevertheless dependence on calcium of the human red cell may be demonstrated after suitable treatment of the cells in conformity with earlier work by Maizels ${ }^{6}$ and Wilbrandt? . The former showed that human red cells became highly permeable to cations when placed in an electrolyte-free medium (for example, glucose), unless about $10 \mathrm{~m} M$ sodium or potassium chloride were present, while Wilbrandt found sodium and potassium chlorides to be less effective than the salts of the alkaline earths, though there was no specificity within this group, the actions of calcium, magnesium, strontium and barium being quantitatively similar.

The treatment of red cells used in the present investigation involves three stages, details of which are shown in Table 1 . In stage 1 (depletion stage) red

Table 1. EFFects of the SAITS OF the ALKaIINe EARThS ON THF Permeability of Modified HUMan Red Celis to Monovalent Cations.

\begin{tabular}{|c|c|c|c|c|}
\hline \multirow[t]{2}{*}{ Additions } & \multirow[t]{2}{*}{$\mathrm{m} M$} & \multicolumn{3}{|c|}{$\begin{array}{l}\text { Ratio of the cation fux per hour to the } \\
\text { concentration difference between cells } \\
\text { and the external medium }\end{array}$} \\
\hline & & Sodium in & $\begin{array}{l}\text { Potassium } \\
\text { out }\end{array}$ & $\begin{array}{c}\text { Lithium } \\
\text { out }\end{array}$ \\
\hline None & - & 0.31 & $0 \cdot 28$ & 0.44 \\
\hline $\mathrm{MgCl}_{8}$ & 2.5 & 0.28 & 0.31 & 0.41 \\
\hline $\mathrm{SrCl}_{3}$ & $2 \cdot 5$ & 0.25 & 0.25 & 0.35 \\
\hline $\mathrm{BaCl}_{2}$ & $2 \cdot 5$ & 0.30 & $0 \cdot 31$ & 0.43 \\
\hline $\mathrm{CaCl}_{2}$ & $2 \cdot 5$ & 0.04 & 0.06 & 0.07 \\
\hline
\end{tabular}

Note: Cells were first incubated for $3 \mathrm{hr}$. at $37^{\circ} \mathrm{C}$. in lactose solution ( 6 per cent $\mathrm{w} / \mathrm{v}$ ), then for $1 \frac{1}{2} \mathrm{hr}$. in a solution of potassium and lithium chloride (70 mM of each), and finally transferred to sodium chioride solution (140 mM for $1 \mathrm{hr}$. at $37^{\circ} \mathrm{C}$. Additions of calcium chloride, stage, during which cation exchanges were measured.

cells are incubated in lactose solution, which increases permeability twenty-fold: natural sodium and potassium leak from the cells accompanied by water and the cells shrink. In stage 2 (cation replacement stage) the cells are transferred to an electrolyte medium; one containing a mixture of potassium and lithium chloride is suitable. Here, potassium chloride, lithium chloride and water enter the cells, and it would be possible to measure penetration-rates in this stage, were it not for the uncertainty in correcting for the considerable swelling which now occurs. Hence it is necessary to proceed to stage 3 (cation exchange stage) and transfer the cells (now containing potassium and lithium) to a different electrolyte medium, usually sodium chloride solution. In this stage potassium and lithium leave the cells, whilst sodium enters, changes in volume of the cells being slight. If to a series of such suspensions, chlorides of mag. nesium, strontium, barium or calcium are respectively added, cation penetration is rapid in the case of the first three, and slow in the presence of calcium. This is shown in Table 1 where permeability is expressed as the ratio of the cation flux per hour to the mean difference in concentration between cells and medium.
Maizels' and Wilbrandt's earlier observations suggest that if red cells are suspended in a solution of non-electrolyte and monovalent cations or certain divalent cations are added at once, then normal low cell permeability is maintained, and that in the absence of such eations low permeability is lost. The present observations show that once relative impermeability has been lost in this way, calcium alone can restore it. This may well be true of other cells, including the unfertilised egg of the sea-urchin which in sea-water is only slightly permeable to water, but becomes highly permeable in non-electrolyte media unless either calcium or magnesium chloride is added ${ }^{8}$. It is suggested that some substance is present in the red cell membrane which contributes to low permeability, that loss of this substance is prevented by various cations, but that replacement can only be effected by calcium. It is possible that the substance itself is a calcium compound; if so, it can only be present in trace amounts.

\section{Department of Clinical Pathology, \\ University College Hospital, London, W.C.1.} June 10.

\section{Maizels, M., J. Physiol., 132, 414 (1956).}

Lyman, R. A., J. Cell Comp. Physiol. 25, 65 (1945).

2 Black, E. C., and Irving, L., J. Cell. Comp. Physiol., 12, 255 (1938).

"Ferguson, J. K. W. Horvath, S. M., and Pappenheimer, J. R., J. Cell Comp, Physiol., 75, 381 (1938)

$\checkmark$ Hamdi. T. N., and Ferguson, J. K. W., Proc. Soc. Exp. Biol. Med., 44, $427(1940)$.

; Maizels, M., Biochem. J., 29, 1970 (1935).

Tilbrandt, W. Pfug , Arch ges. Physiol. 243,537 (1940).

B. McCutcheon, M.., and Lucke, B., J. gen. Physiol., 12, 129 (1928).

\section{Splenic Siderosis in Mice Treated with Dithiourethane}

IN an attempt to elucidate the mode of action of urethane (ethyl carbamate) as a carcinogen for mice, its dithio analogue $\left(\mathrm{NH}_{2} \mathrm{CSSC}_{2} \mathrm{H}_{5}\right)$ was prepared ${ }^{1,2}$ and a study was made of its lethal dose and general toxic effects before testing it for carcinogenicity. A report of the latter is in preparation. The short-term tests revealed an action of this compound whose significance is, at the moment, rather obscure.

$C B A$ strain mice of both sexes were injected subcutaneously with $0.15 \mathrm{ml}$. of a 5 per cent solution of dithiourethane in arachis oil. After three or more weekly injections, a brown pigment in hæmatoxylin and eosin-stained sections of the spleen was seen in all cases. When, on a few occasions, stock outbred mice were used, the same phenomenon occurred. The pigment also appeared in unstained sections and was found to contain iron by the Prussian blue test. It was distributed in the macrophages of the perifollicular reticulo-endothelial tissue (Fig. 1). The spleens of mice injected with the solvent (arachis oil) alone, of mice treated with $0.2 \mathrm{ml}$. of a 5 per cent aqueous urethane solution for the same time and of untreated mice, all showed considerably smaller amounts of the pigment scattered throughout the spleen (Fig. 2). A number of other organs of the same mice were examined histologically as a routine in these tests, and no evidence of this pigment was ever found in liver, kidney, lung, axillary lymph node or testis. Nor was any seen in pancreas when, on occasion, a piece was accidentally included in the section with spleen.

In the long-term experiments, weekly injections were carried out for up to three months. The amount of pigment deposited in the spleen was found to be proportional to the number of treatments during that time. When treatment stopped the amount of pigment 